\title{
Serum Netrin-1 and Asymmetric Dimethylarginine as Biomarkers of Acute and Chronic Carbon Monoxide Poisoning
}

\author{
Eslam S. Metwally ${ }^{1}$; Omayma M. Hassan² ${ }^{2}$ Abdelmonem G. Madboly ${ }^{1}$
}

\begin{tabular}{ll}
\hline & ABSTRACT \\
\cline { 2 - 3 } $\begin{array}{l}\text { KEYWORDS } \\
\text { Netrin-1 (Net-1), } \\
\text { Asymmetric dimethylarginine } \\
\text { (ADMA), }\end{array}$ & $\begin{array}{l}\text { Diagnosis of carbon monoxide (CO) poisoning is done traditionally by } \\
\text { detecting carboxyhemoglobin (COHb) level. However, the severity of clinical } \\
\text { marbon monoxide, } \\
\text { Poisoning, }\end{array}$ \\
$\begin{array}{l}\text { protein with anti-inflammatory and anti-apoptotic properties while asymmetric } \\
\text { dimethylarginine (ADMA) is an oxidative stress indicator. This study aimed at } \\
\text { Clinical study. }\end{array}$ & $\begin{array}{l}\text { assessing and comparing between Net-1, ADMA and COHb as biomarkers in } \\
\text { CO poisoning. This cross-sectional clinical study was carried out on } 30 \text { acutely }\end{array}$ \\
CO poisoned adults admitted to Benha Poisoning Control Unit, Benha University \\
Hospitals; 30 chronic CO exposed workers at four different car service centres, \\
plus 30 healthy controls. Results showed a positive correlation between serum \\
levels of Net-1 and ADMA and the severity of acute CO poisoning both on \\
admission, and after oxygen therapy. There was a positive correlation between \\
COHb level and both serum levels of Net-1 and ADMA in chronic cases. In \\
conclusion: COHb level can only support the initial diagnosis of acute CO \\
poisoning. Both ADMA and Net-1 are better biomarkers in assessing the severity \\
of acute CO poisoning, where ADMA is better than Net-1. In diagnosis of \\
chronic CO poisoning, both ADMA and Net-1 are as dependable as COHb.
\end{tabular}

\section{Introduction}

Carbon monoxide (CO) is an odorless, colorless, nonirritant gas, it is lighter than air, and produced by partial combustion of carbon containing compounds. It is often called the "silent killer" as victims of CO poisoning lose

\footnotetext{
(1) Forensic Medicine and Clinical Toxicology Department, Faculty of Medicine, Benha University, Egypt

(2) Community, Environmental and Occupational Medicine Department, Faculty of Medicine, Benha University, Egypt

Corresponding Author:

Abdelmonem G. Madboly: Forensic Medicine and Clinical Toxicology Department, Faculty of Medicine, Benha University, Egypt.

Address: Faculty of Medicine, Benha University. Farid Nada Street, Benha City, Qalubia, Egypt.

Postal code: 13518

Email:abdelmonem.algohari@fmed.bu.edu.eg

monemmadboly@gmail.com

ORCID ID: https://orcid.org/0000-0002-4333-9018

Mobile No: +201118734643
}

their consciousness even before they realize that they are being poisoned (Jung and Lee, 2019).

Both acute and chronic poisonings occur due to $\mathrm{CO}$ exposure; acute poisoning results from inhalation of CO-containing air in closed spaces, whereas chronic poisoning is detected among people working in industries as a result of continuous prolonged exposure to low $\mathrm{CO}$ concentrations (Koyuncu et al., 2019).

Acute $\mathrm{CO}$ poisoning affects multiple organ systems with no typical clinical picture (non-specific presentation); therefore, misdiagnosis is a common possibility (Reumuth et al., 2019).

Chronic $\mathrm{CO}$ poisoning has rarely been reported despite being more prevalent and 
associated with increased morbidity and mortality than previously reported (Bol et al., 2018).

Pathological effects of $\mathrm{CO}$ poisoning are caused by hypoxia, in addition, $\mathrm{CO}$ poisoning produces reactive oxygen species, and oxidative stress that induces immunological and inflammatory damages to all body organs (Huang et al., 2019).

Diagnosis of CO poisoning is done by detecting the percentage of carboxyhemoglobin $(\mathrm{COHb})$ in the arterial blood. However, the severity of clinical picture is unrelated to the absolute levels of $\mathrm{COHb}$, which is the routine biomarker of $\mathrm{CO}$ poisoning (Reumuth et al., 2019).

Therefore, detection of new and better biomarkers that can diagnose the severity and outcome of CO poisoning is essential (Yazar et al., 2019).

Netrin-1 (Net-1) is a laminin-related protein that alleviates cellular infiltration and inflammation by suppressing inflammatory cytokines and chemokines. Net-1 inhibits the apoptosis of endothelial and neuronal cells and improves neuronal and vascular regeneration after ischemic injury (Gedikli et al., 2019; Guo et al., 2019).

Asymmetric dimethylarginine (ADMA) has structural similarity to the amino acid Larginine. It is an oxidative stress indicator as it inhibits the synthase of nitric oxide. So, levels of ADMA increase in the course of oxidative stress, inflammation, and endothelial dysfunction (Liyona et al., 2019).

Few published researches studied the role of either Net-1 or ADMA in diagnosis of acute $\mathrm{CO}$ poisoning; and no study was conducted to compare between Net-1 and
ADMA as diagnostic biomarkers of both acute and chronic $\mathrm{CO}$ poisonings.

Therefore this work aimed at assessing the role of serum Net-1 and ADMA levels as possible biomarkers for diagnosis of both acute and chronic $\mathrm{CO}$ poisoning; determining the correlation between serum Net-1 and ADMA levels and the severity of acute $\mathrm{CO}$ poisoning, and comparing between Net-1, $\mathrm{ADMA}$ and $\mathrm{COHb}$ levels as biomarkers in $\mathrm{CO}$ poisoning.

\section{Subjects and Methods}

This cross-sectional clinical study was carried out on 60 cases of both acute and chronic $\mathrm{CO}$ poisoning, plus 30 healthy controls, as follows:

Thirty adult patients (aged $>18$ years) admitted to Benha Poisoning Control Unit (BPCU), Benha University Hospitals, Egypt, with acute $\mathrm{CO}$ poisoning. Thirty chronic $\mathrm{CO}$ exposed male workers; working at four different car service centres for at least five years, six work shifts/week, 8 hours/shift, of age $>18$ years, in Benha City, Qalubia Governorate, Egypt. Thirty healthy volunteers of the same age and sex distribution as test group, were enrolled in the study as a control group to determine the mean average normal values of $\mathrm{COHb}$, Net-1 and ADMA levels.

\section{Exclusion criteria:}

1. Patients who are proven by history, physical examination, or investigations to have any chronic inflammatory conditions or chronic diseases such as cardiovascular, lung, kidney, liver diseases, haemolytic anaemia and malignancy. 
2. Smoking.

3. Patients refused to give informed consent, or their relatives do so [in unconscious patients].

4. Pregnancy.

\section{All included subjects were evaluated according to the followings: -}

1- Demographic study: age, gender, home heating devices, plus duration of daily exposure (in chronic cases).

2- Clinical study:

- Clinical manifestations detected by history taking and physical examination.

- Severity of poisoning in acute patients either at admission $\left(0^{\text {th }} h\right)$ or after oxygen therapy $\left(6^{\text {th }} \mathrm{h}\right)$, was classified according to poisoning severity score (PSS), describe by Persson et al. (1998).

- Treatment measures done to acute patients; according to Tomaszewski (2006). All patients were treated using normobaric oxygen as hyperbaric oxygen was not available.

3-Investigational study:

A) Blood samples: in acute cases, blood samples were taken twice; the first samples were taken at admission of patient $\left(0^{\text {th }} \mathrm{h}\right)$, the second samples were taken after oxygen therapy $\left[6^{\text {th }} \mathrm{h}\right]$, meanwhile in chronic cases, blood samples were taken once, at mid-day work, from workers presenting with any of the chronic manifestations known by history taking.

B) Carboxyhemoglobin ( $\mathrm{COHb})$ levels:

- Immediately after collection of $2 \mathrm{ml}$ of arterial blood samples; $\mathrm{COHb}$ level was measured by a spectrometry assay and expressed as a percentage of plasma hemoglobin, using a blood gas analyzer [ABL800 FLEX blood gas analyser (Radiometer America Inc.)] with a multiwavelength spectrometer, absorbing the visible light from 478 to $672 \mathrm{~nm}$ as described by Bono et al. (2007) and Crapo et al. (1999).

- $\mathrm{COHb}$ level $>5 \%$ was considered as diagnostic criteria for $\mathrm{CO}$ poisoning, as described by Koyuncu et al. (2019).

C) Serum netrin-1 (Net-1) and serum asymmetric dimethyl arginine (ADMA) levels:

- Three ml venous blood samples were collected in Vacutainer tubes and allowed to clot.

- Both were measured by Enzyme-Linked Immunosorbent Assay (ELISA) technique, based on the Biotin double antibody sandwich technology, by BioRad PR4100 ${ }^{\circledR}$ (France) ELISA plate reader device.

- Serum Net-1 levels were measured using human Netrin-1 ELISA Kit, Bioassay (China), Cat\# E1277Hu, following the manufacturer's protocol, as described by Ramesh et al. (2011). Standard detection curve range: $10 \mathrm{pg} / \mathrm{ml}-3000 \mathrm{pg} / \mathrm{ml}$.

- Serum ADMA levels were measured using human asymmetrical dimethylarginine (ADMA) ELISA Kit, Bioassay (Shanghai Crystal Day Biotech Co., Ltd. China), Cat\# E4539Hu, following the manufacturer's instructions, as described by Schulze et al. (2004). Assay range: $0.05 \mathrm{nmol} / \mathrm{ml}-$ $4 \mathrm{nmol} / \mathrm{ml}$.

The study protocol was approved by the Research Ethics Committee of Benha Faculty of Medicine, Benha University 
[certificate No. 1017; 2019]. An informed consent was taken from each participant in this study. All results obtained were registered in special sheets of the study, which were confidential.

\section{Statistical analysis}

The collected data were analyzed using SPSS version 21 software (SpssInc, Chicago, ILL Company). Categorical data were presented as number and percentages. Quantitative data were expressed as mean \pm standard deviation if normally distributed or median and range if not. Man Whitney $U$ test $\left(Z_{\mathrm{MWU}}\right)$ was used for nonparametric variables among two independent groups, while Kruskal Wallis test $(\mathrm{KW})$ for three independent groups. Matched nonparametric variables were assessed by Wilcoxon test. Nonparametric correlations were assessed by Spearman's correlation coefficient (rho). ROC curves were constructed to determine cutoff values of the studied biomarkers with optimum sensitivity and specificity in prediction of severity grades. $\mathrm{P} \leq 0.05$ was considered significant (Khothari, 2004).

\section{Results}

Majority of acute $\mathrm{CO}$ poisoning cases $(83.3 \%)$ were males. The mean age of cases was $34.8 \pm 10.7$ (ranging from 19 to 51 years). Heating devices were found at homes of about $81 \%$ of cases.
All chronic $\mathrm{CO}$ exposure cases were males, with a mean age of $38.6 \pm 10.3$ (ranging from 24 to 55 years). Heating devices were found at homes of $47 \%$ of cases. The mean duration of daily $\mathrm{CO}$ exposure was $5.2 \pm 0.86$, with a range of 4-6 hours.

The most common representing manifestations of acute $\mathrm{CO}$ poisoning cases were headache $(96.7 \%)$, dizziness $(90.0 \%)$ and confusion (66.7\%). On admission, and according to PSS, 15 patients (50\%) were mild, ten patients $(33.3 \%)$ were moderate and five patients $(16.7 \%)$ were severe. Fourteen patients $(46.7 \%)$ were treated with $100 \% \mathrm{O} 2$ applied by non-rebreather (reservoir) face mask; 11 patients $(36.7 \%)$ were treated with $\mathrm{O} 2$ by nasal canula or nasal mask and five patients $(16.7 \%)$ were treated with $100 \% \mathrm{O} 2$ applied by endotracheal tube. Most of patients $(53.3 \%)$ became asymptomatic after $\mathrm{O} 2$ therapy and were discharged.

Most of cases with chronic $\mathrm{CO}$ exposure were manifested by persistent headache (66.7\%); palpitation (60\%); dyspnea $(56.7 \%)$ and dizziness $(43.3 \%)$.

As regard cases of acute $\mathrm{CO}$ poisoning: the median serum level of $\mathrm{COHb}$ on admission (0th h) was $9.5 \%$, which was significantly high $(\mathrm{p}<0.001)$ as compared with controls $(2.0 \%)$, meanwhile the median serum level of $\mathrm{COHb}$ after oxygen therapy $\left(6^{\text {th }} h\right)$ was $2.0 \%$, which was significantly decreased $(p<0.001)$, as compared with $0^{\text {th }} \mathrm{h}$ level, (details showed in Table 1). 
Table (1): Comparison between cases of acute $\mathrm{CO}$ poisoning and controls regarding serum levels of carboxyhemoglobin (COHb); netrin-1 (Net-1) and asymmetric dimethyl arginine (ADMA) on admission $\left(0^{\text {th }} h\right)$ and after oxygen therapy $\left(6^{\text {th }} h\right)$ :

\begin{tabular}{|c|c|c|c|c|c|c|c|c|c|}
\hline \multirow{2}{*}{ Variable } & \multicolumn{2}{|c|}{$\begin{array}{c}\text { Controls } \\
(\mathrm{n}=30)\end{array}$} & \multicolumn{2}{|c|}{$0^{\text {th }} h(n=30)$} & \multicolumn{2}{|c|}{$6^{\text {th }} h .(n=30)$} & \multirow{2}{*}{$\mathbf{Z}_{\text {MWU1 }}(\mathbf{P})$} & \multirow{2}{*}{$\begin{array}{c}\text { Wilcoxon } \\
\text { test (P) }\end{array}$} & \multirow{2}{*}{$\mathbf{Z}_{\text {MWU2 }}(\mathbf{P})$} \\
\hline & Median & Range & Median & Range & Median & Range & & & \\
\hline $\mathrm{COH}$ & 2.0 & $0-5$ & 9.5 & $5-22$ & 2.0 & $1-5$ & $\begin{array}{c}6.67 \\
* * *(<0.001)\end{array}$ & $\begin{array}{c}4.79 \\
* * *(<0.001)\end{array}$ & $\begin{array}{c}0.98 \\
(0.32)\end{array}$ \\
\hline $\begin{array}{l}\text { Net-1 } \\
(\mathrm{pg} / \mathrm{ml})\end{array}$ & 400.5 & $\begin{array}{l}337- \\
474\end{array}$ & 715.0 & $\begin{array}{l}600- \\
1200\end{array}$ & 779.5 & $\begin{array}{l}634- \\
1166\end{array}$ & $\begin{array}{c}6.65 \\
* * *(<0.001)\end{array}$ & $\begin{array}{c}4.64 \\
* * *(<0.001)\end{array}$ & $\begin{array}{c}6.65 \\
* * *(<0.001)\end{array}$ \\
\hline $\begin{array}{l}\text { ADMA } \\
\text { (nmol/L) }\end{array}$ & 0.71 & $\begin{array}{l}0.6- \\
0.95\end{array}$ & 0.855 & $\begin{array}{l}0.6- \\
1.97\end{array}$ & 1.58 & $\begin{array}{l}0.98- \\
3.16\end{array}$ & $\begin{array}{c}3.98 \\
* * *(<0.001)\end{array}$ & $\begin{array}{c}4.78 \\
* * *(<0.001)\end{array}$ & $\begin{array}{c}6.65 \\
* * *(<0.001)\end{array}$ \\
\hline
\end{tabular}

$\mathbf{Z}_{\text {MwU1 }}(\mathbf{P})$ : between controls and acute $0 \mathrm{~h}$; Wilcoxon test $(\mathbf{P})$ : between acute at 0 and $6 \mathrm{~h} ; \mathbf{Z}_{\mathbf{M w U} 2}(\mathbf{P})$ : between controls and acute $6 \mathrm{~h} ;{ }^{* * *}$ : highly significant; $\mathbf{C O H b}$ : carboxyhemoglobin; ADMA: asymmetric dimethyl arginine; Net-1: netrin-1

Meanwhile, on admission, the median serum levels of Net-1 and ADMA were 715 $\mathrm{pg} / \mathrm{mL}$ and $0.855 \mathrm{nmol} / \mathrm{L}$, respectively, which were significantly high $(\mathrm{p}<0.001)$ as compared with controls $(400.5 \mathrm{pg} / \mathrm{mL}$ and 0.71 $\mathrm{nmol} / \mathrm{L}$, respectively), meanwhile the median serum levels of Net-1 and ADMA after oxygen therapy were $779.5 \mathrm{pg} / \mathrm{mL}$ and 1.58 $\mathrm{nmol} / \mathrm{L}$, respectively, which were significantly increased $(\mathrm{p}<0.001)$ as compared with $0^{\text {th }} \mathrm{h}$ levels, (details showed in table 1).

There was a positive correlation between serum levels of $\mathrm{COHb}$ and severity of acute CO poisoning, which was statistically significant $(\mathrm{p}<0.001)$ at $0^{\text {th }} \mathrm{h}$, meanwhile it became non-significant at $6^{\text {th }} \mathrm{h}$, (details showed in table 2 and figure 1).

Table (2): Spearman's correlation coefficient between the studied biomarkers (COHb; Net-1 and ADMA) and the poisoning severity score (PSS), at admission $\left(0^{\text {th }} \mathrm{h}\right)$ and after oxygen therapy $\left(6^{\text {th }} h\right)$ in acute $\mathrm{CO}$ poisoning cases:

\begin{tabular}{|c|c|c|}
\hline \multicolumn{3}{|c|}{ PSS at admission $\left(0^{\text {th }} h\right)(n=30)$} \\
\hline Variable & rho & p value \\
\hline COHb & 0.650 & $* * *<0.001(\mathrm{HS})$ \\
\hline Net-1 (pg/ml) & 0.731 & $* * *<0.001(\mathrm{HS})$ \\
\hline ADMA (nmol/L) & 0.810 & $* * *<0.001(\mathrm{HS})$ \\
\hline \multicolumn{3}{|c|}{ PSS at admission $\left(6^{\text {th }} h\right)(n=30)$} \\
\hline Variable & rho & p value \\
\hline $\mathrm{COHb}$ & 0.089 & $0.64(\mathrm{NS})$ \\
\hline Net-1 (pg/ml) & 0.736 & $* * *<0.001(\mathrm{HS})$ \\
\hline ADMA (nmol/L) & 0.787 & $* * *<0.001(\mathrm{HS})$ \\
\hline
\end{tabular}

***: Very highly significant; COHb: carboxyhemoglobin; ADMA: asymmetric dimethyl arginine; Net-1: netrin-1;

PSS: poisoning severity score; rho: spearman's correlation coefficient; HS: highly significant; NS: nonsignificant.

There was a positive correlation between serum levels of Net-1 and ADMA and the severity of acute $\mathrm{CO}$ poisoning, this

correlation was found to be statistically significant $(\mathrm{p}<0.001)$ at $0^{\text {th }} \mathrm{h}$, and at $6^{\text {th }} \mathrm{h}$, (details showed in table 2 and figure 2). 

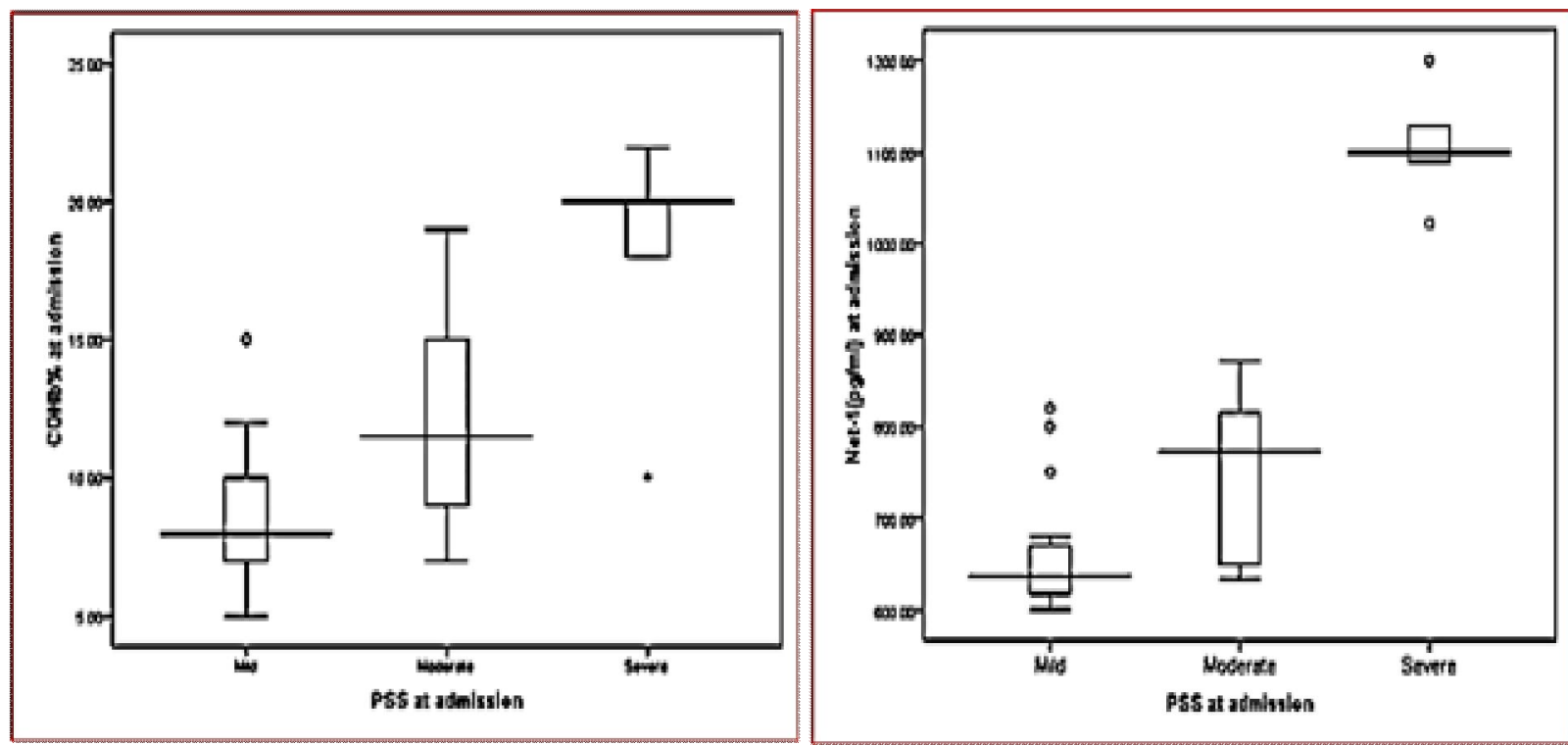

$\begin{array}{llll}\text { Median: } & \$ .0 & 11.5 & 20.0 \\ \text { Range: } & 5.15 & 7.19 & 10.22\end{array}$

Median: 6370

Range: $600-820$
1100.0

$634-871 \quad 1022.1200$

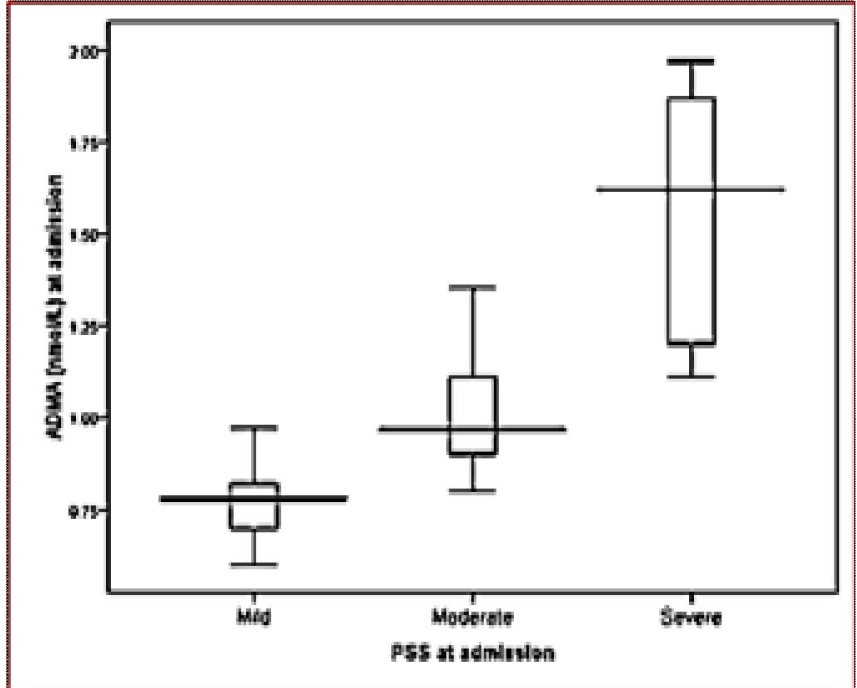
Median: $\quad 0.78$
0.97
1.62
Range: $\quad 0.6-0.97$
$0.8 \cdot 1.35$
$1.11 \cdot 1.97$

Fig. (1): Box plot showing the median and range of studied biomarkers [carboxyhemoglobin (COHb); netrin-1 (Net-1) and asymmetric dimethylarginine (ADMA)] in relation to the poisoning severity score (PSS) of acute $\mathrm{CO}$ poisoning cases on admission $\left(0^{\text {th }} \mathrm{h}\right)$. 


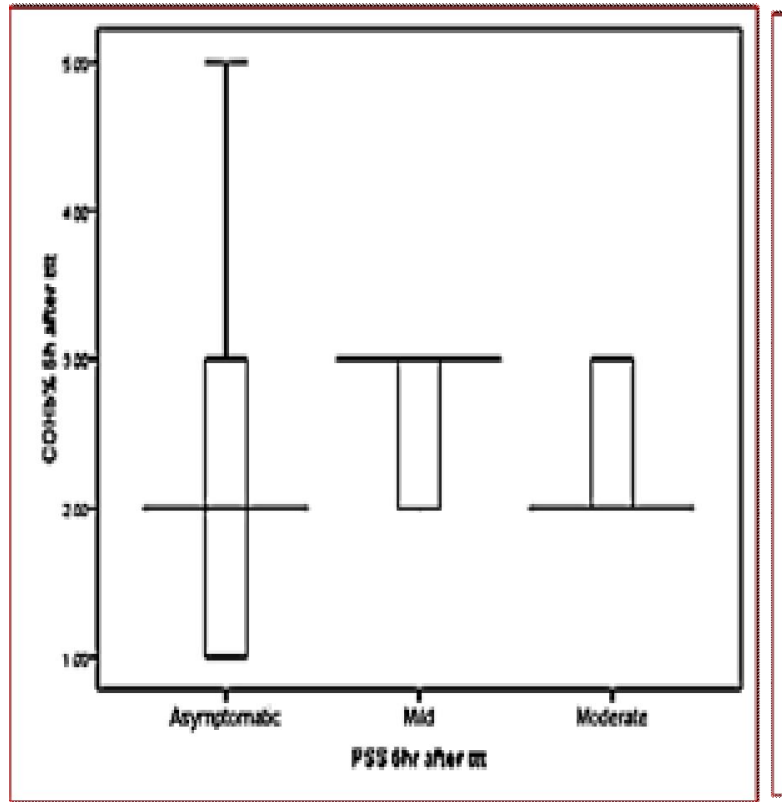

Median: 2.0

Range 1.5
30

$2-3$
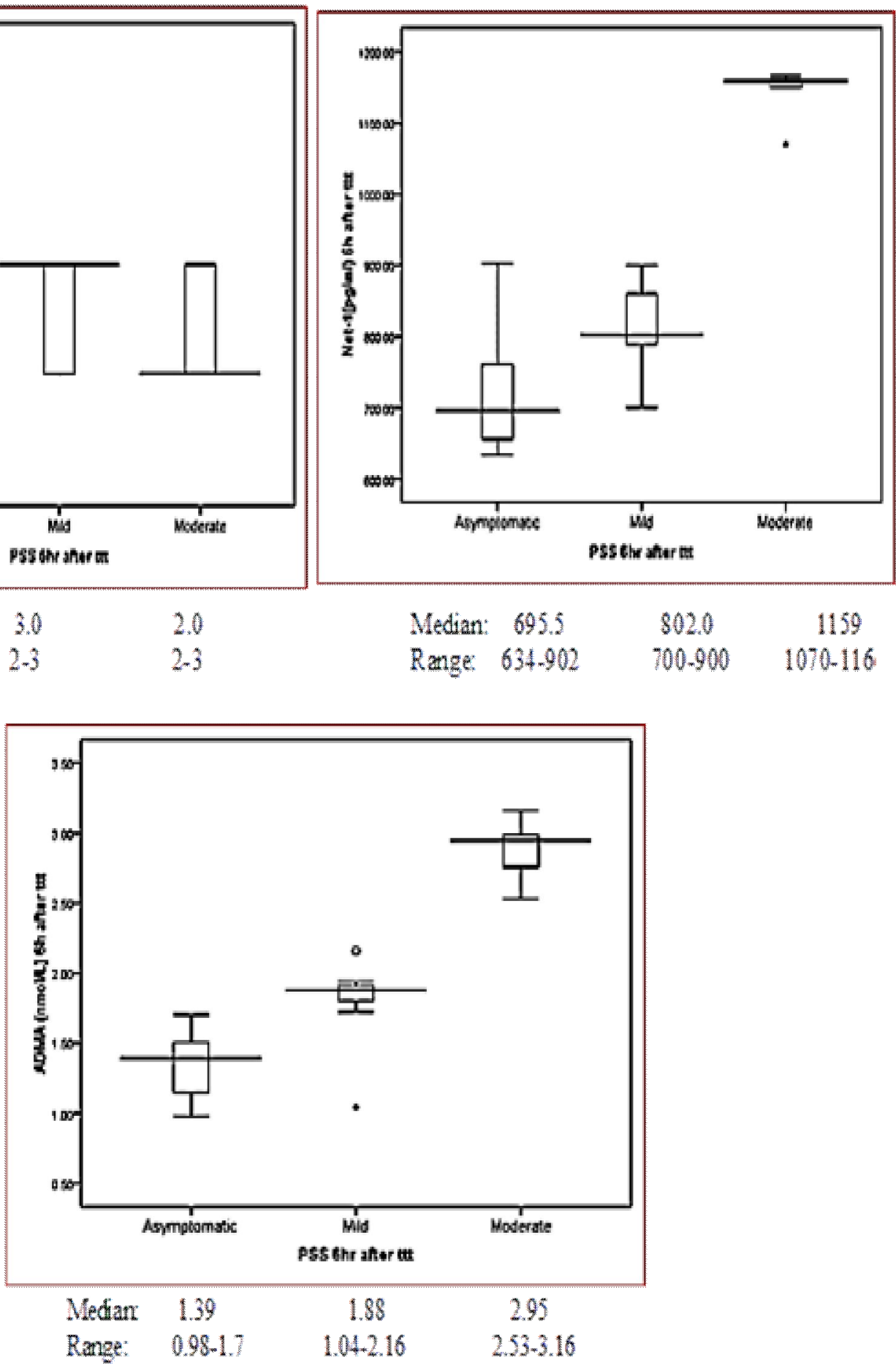

Fig. (2): Box plot showing the median and range of studied biomarkers [carboxyhemoglobin $(\mathrm{COHb})$; netrin-1 (Net-1) and asymmetric dimethylarginine (ADMA)] in relation to the poisoning severity score (PSS), after oxygen therapy $\left(6^{\text {th }} \mathrm{h}\right)$ of acute $\mathrm{CO}$ poisoning cases. 
Receiver operator characteristic (ROC) curves were done to compare between serum Net-1, ADMA and $\mathrm{COHb}$ levels as biomarkers in acute $\mathrm{CO}$ poisoning, results illustrated that Net-1 and ADMA were more accurate and sensitive biomarkers as compared with $\mathrm{COHb}$.
The ROC curves illustrated also that ADMA is more accurate and sensitive biomarker as compared with Net-1. These results were statistically significant ( $p<0.001)$, (details showed in tables $3 \& 4$ and figures $3 \& 4$ ).

Table (3): Cutoff values, area under the curve (AUC) and confidence interval (CI) of receiver operator characteristic (ROC) curve for comparing accuracy and performance of the studied biomarkers to differentiate moderate/severe from mild cases of acute $\mathrm{CO}$ poisoning on $\operatorname{admission}\left(0^{\text {th }} \mathrm{h}\right)$ :

\begin{tabular}{|l|c|c|c|c|c|c|c|c|}
\hline \multicolumn{1}{|c|}{ Score } & $\begin{array}{c}\text { Cutoff } \\
\text { values }\end{array}$ & $\begin{array}{c}\text { Sensitivity } \\
\mathbf{\%}\end{array}$ & $\begin{array}{c}\text { Specificity } \\
\mathbf{\%}\end{array}$ & $\begin{array}{c}\text { PPV } \\
\mathbf{\%}\end{array}$ & $\begin{array}{c}\text { NPV } \\
\mathbf{\%}\end{array}$ & AUC & $\begin{array}{c}\mathbf{9 5 \%} \\
\text { CI }\end{array}$ & p value \\
\hline COHb & $\geq 9.5$ & $73.3 \%$ & $73.3 \%$ & $73.3 \%$ & $73.3 \%$ & 0.833 & $0.68-0.98$ & $* * 0.002$ \\
\hline Net-1(pg/ml) & $\geq 715$ & $80 \%$ & $80 \%$ & $80 \%$ & $80 \%$ & 0.867 & $0.74-0.99$ & $* * 0.001$ \\
\hline ADMA (nmol/L) & $\geq 0.88$ & $86.7 \%$ & $93.3 \%$ & $92.8 \%$ & $87.5 \%$ & 0.933 & $0.85-1.0$ & $* * *<0.001$ \\
\hline
\end{tabular}

PPV: positive predictive value; NPV: negative predictive value; ** : highly significant; ***: very highly significant; AUC: area under the curve; CI: confidence interval; COHb: carboxyhemoglobin; ADMA: asymmetric dimethyl arginine; Net-1: netrin-1.

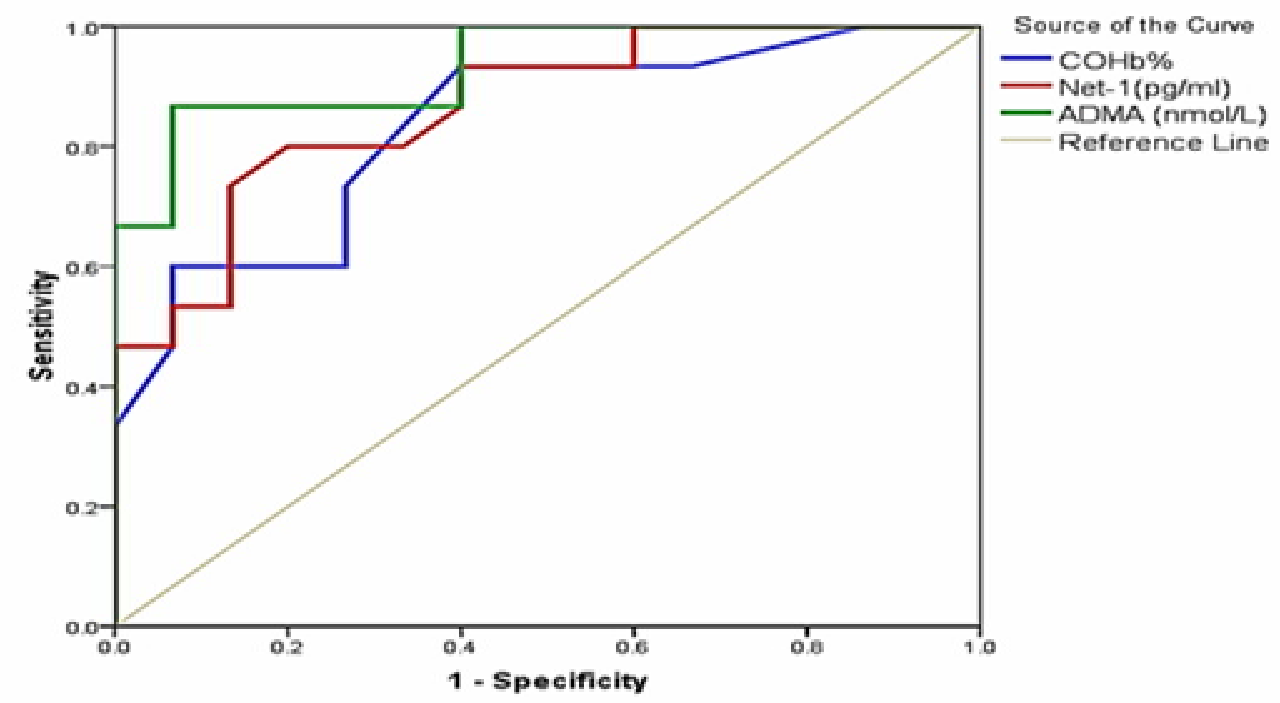

Fig. (3): Receiver operator characteristic (ROC) curve for comparing accuracy and performance of the studied biomarkers [carboxyhemoglobin $(\mathrm{COHb})$; netrin-1 (Net-1) and asymmetric dimethylarginine (ADMA)] to differentiate moderate/severe from mild cases of acute $\mathrm{CO}$ poisoning on admission $\left(0^{\text {th }} \mathrm{h}\right)$. Related cutoff values, area under the curve (AUC) and confidence interval (CI) of receiver operator characteristic (ROC) were illustrated in table (3). 
Table (4): Cutoff values, Area Under the Curve (AUC) and Confidence Interval (CI) of receiver operator characteristic (ROC) curve for comparing accuracy and performance of the studied biomarkers to differentiate moderate/severe from mild cases of acute $\mathrm{CO}$ poisoning after oxygen therapy $\left(6^{\text {th }} h\right)$ :

\begin{tabular}{|l|c|c|c|c|c|c|c|c|}
\hline \multicolumn{1}{|c|}{ Score } & $\begin{array}{c}\text { Cutoff } \\
\text { values }\end{array}$ & $\begin{array}{c}\text { Sensitivity } \\
\mathbf{\%}\end{array}$ & $\begin{array}{c}\text { Specificity } \\
\mathbf{\%}\end{array}$ & $\begin{array}{c}\text { PPV } \\
\mathbf{\%}\end{array}$ & $\begin{array}{c}\text { NPV } \\
\mathbf{\%}\end{array}$ & AUC & $\begin{array}{c}\mathbf{9 5 \%} \\
\text { CI }\end{array}$ & p value \\
\hline COHb & $\geq 2.5$ & $50 \%$ & $56.2 \%$ & $50 \%$ & $56.2 \%$ & 0.562 & $0.35-0.78$ & 0.56 \\
\hline Net-1(pg/ml) & $\geq 779.5$ & $85.7 \%$ & $81.2 \%$ & $80 \%$ & $86.7 \%$ & 0.877 & $0.75-1.0$ & $* * *<0.001$ \\
\hline ADMA (nmol/L) & $\geq 1.67$ & $92.9 \%$ & $93.8 \%$ & $92.9 \%$ & $93.8 \%$ & 0.902 & $0.77-1.0$ & $* * *<0.001$ \\
\hline
\end{tabular}

PPV: positive predictive value; NPV: negative predictive value; ***: very highly significant; AUC: area under the curve; CI: confidence interval; COHb: carboxyhemoglobin; ADMA: asymmetric dimethyl arginine; Net-1: netrin-1.

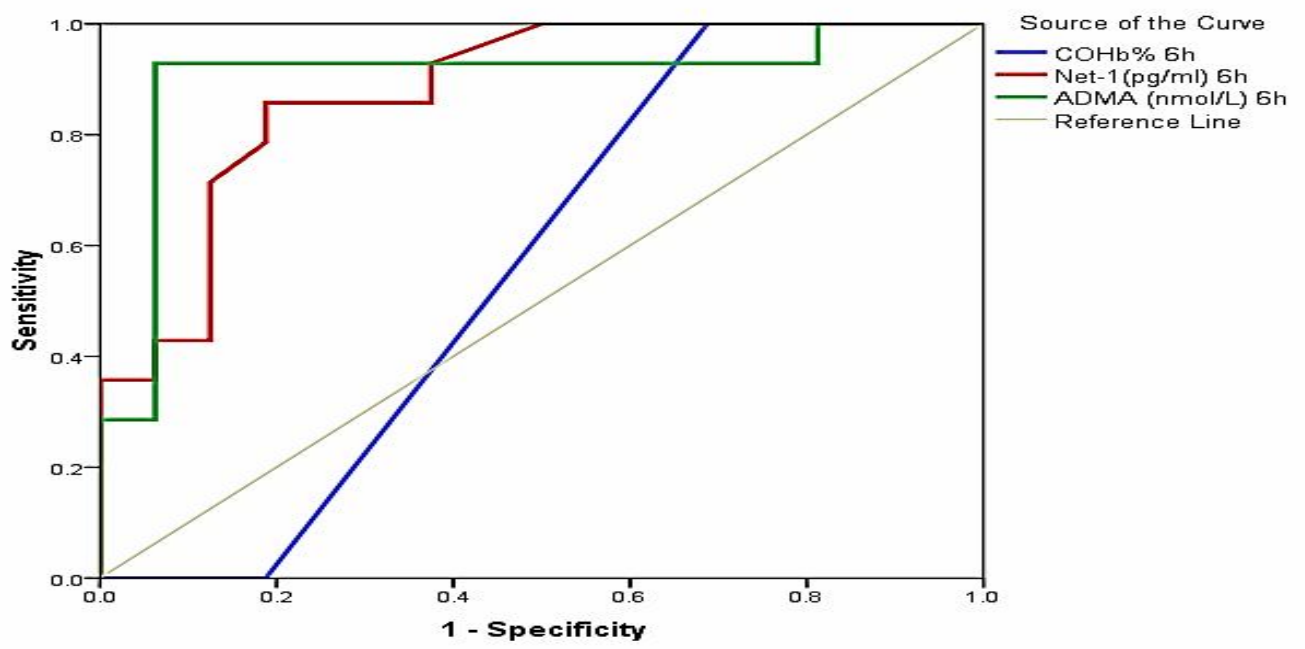

Fig. (4): ROC curve for comparing accuracy and performance of the studied biomarkers [carboxyhemoglobin (COHb); netrin-1 (Net-1) and asymmetric dimethylarginine (ADMA)] to differentiate mild and moderate acute $\mathrm{CO}$ poisoning cases from asymptomatic cases after oxygen therapy $\left(6^{\text {th }} \mathrm{h}\right)$. Related cutoff values, area under the curve (AUC) and confidence interval (CI) of receiver operator characteristic (ROC) were illustrated in table (4).

Table (5): Comparison between serum levels of carboxyhemoglobin ( $\mathrm{COHb})$; netrin-1 (Net-1) and asymmetric dimethyl arginine (ADMA) of chronic $\mathrm{CO}$ exposed cases and controls:

\begin{tabular}{|c|c|c|c|c|c|}
\hline \multirow{2}{*}{ Variables } & \multicolumn{2}{|c|}{ Controls $(n=30)$} & \multicolumn{2}{|c|}{ Chronic $(n=30)$} & \multirow{2}{*}{$\begin{array}{c}\mathbf{Z}_{\mathrm{MWU}} \\
\text { (P) }\end{array}$} \\
\hline & Median & Range & Median & Range & \\
\hline COHb & 2.0 & $0-5$ & 8.0 & $5-11$ & $6.68 * * *(<0.001)$ \\
\hline Net-1 (pg/ml) & 400.5 & $337-474$ & 749.0 & $613-975$ & $6.65 * * *(<0.001)$ \\
\hline ADMA (nmol/L) & 0.71 & $0.6-0.95$ & 1.27 & $0.75-2.0$ & $6.24 * * *(<0.001)$ \\
\hline
\end{tabular}

***: very highly significant; COHb: carboxyhemoglobin; ADMA: asymmetric dimethyl arginine; Net-1: netrin-1. 
There was a positive correlation between the $\mathrm{COHb}$ level and both serum levels of Net-1 and ADMA in chronic cases; this correlation was found to be statistically significant ( $p$ $<0.001$ ), details are showed in table (6).

Table (6): Spearman's correlation coefficient between the studied biomarkers (COHb; Net-1 and ADMA) in chronic $\mathrm{CO}$ exposed cases:

\begin{tabular}{|l|c|c|c|c|}
\hline \multicolumn{2}{|c|}{ Variables } & COHb & Net-1 (pg/ml) & ADMA (nmol/L) \\
\hline \multirow{2}{*}{$\begin{array}{l}\text { Net-1 } \\
(\mathrm{pg} / \mathrm{ml})\end{array}$} & rho & 0.603 & ---- & 0.557 \\
\cline { 2 - 5 } & $\mathrm{P}$ & $* * *<0.001$ & ---- & $* *=0.001$ \\
\hline \multirow{2}{*}{ ADMA (nmol/L) } & rho & 0.495 & 0.557 & $-\cdots--$ \\
\cline { 2 - 5 } & $\mathrm{P}$ & $* * 0.005$ & $* *=0.001$ & $-\cdots$ \\
\hline
\end{tabular}

***: very highly significant; **: highly significant; COHb: carboxyhemoglobin; ADMA: asymmetric dimethyl arginine; Net-1: netrin-1.

\section{Discussion}

Pathogenesis of $\mathrm{CO}$ poisoning, either in acute or chronic exposure, occurs mainly by two mechanisms; the first mechanism is tissue hypoxia, especially in organs with the highest oxygen demand like the brain and the heart, due to formation of $\mathrm{COHb}, \mathrm{CO}$ can also bind myoglobin and mitochondrial cytochrome oxidases leading to more tissue hypoxia. The second mechanism occurs by production of reactive oxygen species and oxidative stress damages, these effects are longer lasting and independent of hypoxia (Huang et al., 2019; Jung and Lee, 2019).

Eichhorn et al. (2018) concluded that long term pathological tissue damages are detected as a result of acute $\mathrm{CO}$ poisoning, despite $\mathrm{O}_{2}$ therapy that lead to drop of $\mathrm{COHb}$ levels to normal values. They justified these delayed tissue injuries by the effects of $\mathrm{CO}$ poisoning at cellular level, where it leads to the activation of neutrophils, proliferation of lymphocytes, mitochondrial dysfunction, oxidative stress, inflammation, and apoptosis.

Masters et al. (2019) found that clinical diagnosis of CO poisoning is difficult due to its vague symptoms especially in atypical presentations. They also explained the underdiagnosis of $\mathrm{CO}$ poisoning to gaps present between the capacity to detect the blood level of $\mathrm{COHb}$ and the unavailability of other confirmatory tests.

Veronesi et al. (2017) stated that endogenous production of $\mathrm{COHb}$ can occur as a result of some diseases, such as chronic obstructive lung disease, liver cirrhosis or transplantation and haematological diseases such as haemolytic anaemia.

The present study found that on admission $\left(0^{\text {th }} \mathrm{h}\right)$ of cases with acute $\mathrm{CO}$ poisoning, the median serum level of $\mathrm{COHb}$ was $9.5 \%$, which was significantly high as compared with controls $(2.0 \%)$, meanwhile it was significantly decreased after O2 therapy $\left(6^{\text {th }} \mathrm{h}\right)$. The present work also found a statistically significant positive correlation between serum levels of $\mathrm{COHb}$ and severity of acute $\mathrm{CO}$ poisoning, only at $0^{\text {th }} \mathrm{h}$, meanwhile it became non-significant at $6^{\text {th }} \mathrm{h}$ after $\mathrm{O}_{2}$ therapy.

Reumuth et al. (2019) concluded that $\mathrm{COHb}$ level alone is an insufficient marker for assessing the severity of acute $\mathrm{CO}$ poisoning. They also stated that high $\mathrm{COHb}$ level can only support the initial diagnosis of $\mathrm{CO}$ poisoning, and further biomarkers are needed to assess the severity of $\mathrm{CO}$ poisoning.

Yazar et al. (2019) showed that there was a poor correlation between $\mathrm{COHb}$ levels and 
the clinical symptoms and final outcome of acute $\mathrm{CO}$ poisoning cases. They reach to a conclusion that increased $\mathrm{COHb}$ blood levels can help in initial diagnose of acute $\mathrm{CO}$ poisoning but do not conclude possible longterm neuropsychiatric or cardiac consequences. Therefore, finding new and better biomarkers that can predict the duration of treatment and outcome of $\mathrm{CO}$ poisoning is essential.

The current work showed that, in cases of chronic $\mathrm{CO}$ exposure, the median serum level of $\mathrm{COHb}$ was $8.0 \%$, which was significantly high, as compared with controls $(2.0 \%)$. This can be justified as this study was done on workers at four different car service centers $(8 \mathrm{~h} . /$ shift, for at least 5 years); blood $\mathrm{COHb}$ estimation was done at mid-day work where $\mathrm{CO}$ exposure was at its highest level.

Nair et al. (2017) concluded that CO gas is considered as a toxic hazard for car service workers, as it is one of the pollutants from vehicle exhaust which is usually released due to incomplete combustion of fuel.

World Health Organization stated that, in chronic CO exposure, an acceptable blood level of $\mathrm{COHb}$ should not below the level of $2.5 \%$ depending on the $\mathrm{CO}$ levels in the environment and duration of exposure (Bol et al., 2018).

ADMA is present as a natural metabolite in human plasma, and it is considered as an oxidative stress index, it blocks nitric oxide (a potent vasodilator) biogenesis and limit the cellular uptake of L-arginine, and this results in impairment of the endothelial function, leading to promotion of ischemic atherosclerosis (Dymara-Konopka and Laskowska, 2019).

Yazar et al. (2019); Oliva-Damaso et al. (2019) concluded that ADMA is synthesized from arginine by the action of the enzyme protein arginine methyltransferases, while degradation of ADMA occurs by dimethyl arginine dimethylaminohydrolase enzyme. In the course of oxidative stress, whatever its cause, there will be activation of protein arginine methyltransferases enzyme and inhibition of dimethyl arginine dimethylaminohydrolase, leading to increased level of ADMA.

Moreover, high levels of ADMA result in generation of nitric superoxide and peroxynitrite free radicals. These free radicals will inactivate mitochondrial enzymes and cause cell membrane lipid peroxidation with further damage to vascular endothelium (Abass et al., 2017).

The present study found that on admission $\left(0^{\text {th }} \mathrm{h}\right)$ of acute $\mathrm{CO}$ poisoning cases, the median serum level of ADMA was significantly high as compared with controls, meanwhile it was significantly increased after $\mathrm{O}_{2}$ therapy $\left(6^{\text {th }} \mathrm{h}\right)$ as compared with its level on admission. There was a significant positive correlation between serum levels of ADMA and the severity of acute $\mathrm{CO}$ poisoning, at both $0^{\text {th }} \mathrm{h}$, and at $6^{\text {th }} \mathrm{h}$. The present work also showed that in cases of chronic CO exposure, the median serum level of ADMA was significantly increased as compared with controls, with a significant positive correlation between the $\mathrm{COHb}$ levels and serum ADMA levels.

The elevated serum levels of ADMA in either cases of acute or chronic $\mathrm{CO}$ exposure can be justified as ADMA is an oxidative stress biomarker that is elevated as a part of $\mathrm{CO}$-induced progressive oxidative stress.

Yazar et al. (2019) concluded that ADMA levels were significantly increased in patients with $\mathrm{CO}$ poisoning on admission and after $\mathrm{O}_{2}$ therapy when compared with controls, with a positive relation between serum levels of ADMA and the severity of CO poisoning.

Net-1 acts as an anti-inflammatory molecule through inhibition of leukocyte infiltration and cytokine production especially 
in conditions precipitated by hypoxia and/or oxidative stress. Net-1 has neuroprotective functions including preservation of bloodbrain barrier integrity, anti-inflammatory and anti-apoptotic effects (Sun et al., 2019).

Developmentally, Net-1 is a chemical regulator of neural axon guidance and angiogenesis, it has a neuroprotective effect in cases of ischemic brain injury (Chen et al., 2019).

Lin et al. (2018) stated that Net-1 has key roles in neuronal navigation, immune cell migration, angiogenesis, and cell survival. In endothelial cells, Net-1 stimulates nitric oxide production and promotes endothelial cell migration and proliferation.

Daliang et al. (2019) concluded that Net1 at high levels can improve myocardial ischemic-reperfusion injuries, as it can activate nitric oxide synthase enzyme, leading to induction nitric oxide production that in turn protects against ischemic injuries and reduce the area of infarction.

The present study showed that on admission $\left(0^{\text {th }} \mathrm{h}\right)$ of cases with acute $\mathrm{CO}$ poisoning, the median serum level of Net-1 was significantly high as compared with controls, meanwhile it was significantly increased after $\mathrm{O}_{2}$ therapy $\left(6^{\text {th }} \mathrm{h}\right)$ as compared with its level on admission. The present work also found that in cases of chronic $\mathrm{CO}$ exposure, the median serum level of Net-1 was significantly increased as compared with controls, with a significant positive correlation between the $\mathrm{COHb}$ levels and serum Net-1 levels. The elevated serum levels of Net-1 in cases of either acute or chronic $\mathrm{CO}$ exposure were due to its antioxidant and antiinflammatory effects.

Gedikli et al. (2019) found that serum Net-1 levels were significantly increased in patients with $\mathrm{CO}$ poisoning on admission and after $\mathrm{O}_{2}$ therapy when compared with controls. They also found higher Net-1 levels after $\mathrm{O}_{2}$ therapy compared to Net-1 levels on admission. They justified their results as despite the clinical improvement and the decrease in blood $\mathrm{COHb}$ levels, after $\mathrm{O}_{2}$ therapy, toxicity and inflammatory status persist at cellular level resulting in high levels of Net-1.

In the present study, there was a significant positive correlation between serum levels of Net-1 and the severity of acute CO poisoning, at $0^{\text {th }} \mathrm{h}$ and at $6^{\text {th }} \mathrm{h}$.

Nevertheless, Gedikli et al. (2019) stated that Net-1 was not a useful biomarker for determining the severity of $\mathrm{CO}$ poisoning. This can be explained by the fact that the studied $\mathrm{CO}$ poisoned cases in their work were mostly consisted of mild cases and they checked the poisoning severity only on bases of neurological involvement.

In the present study, ROC curves were done to compare between serum ADMA, Net1 , and $\mathrm{COHb}$ levels as biomarkers in acute $\mathrm{CO}$ poisoning, results illustrated that ADMA and Net-1 were more accurate and sensitive biomarkers as compared with $\mathrm{COHb}$. The ROC curves illustrated also that ADMA is more accurate and sensitive biomarker as compared with Net-1.

Veronesi et al. (2017) stated that usage of $\mathrm{COHb}$ as a biomarker of acute or chronic $\mathrm{CO}$ poisoning is limited by the difficult interpretation of $\mathrm{COHb}$ levels. $\mathrm{COHb}$ is a very unstable compound and has a short half-life, and therefore, its rapid degradation could generate false negative results leading to underestimation of $\mathrm{COHb}$ levels. Conversely, overestimation of $\mathrm{COHb}$ levels could occur due to the generation of false positive results in smokers and due to patient comorbidities.

The preference of ADMA as a possible biomarker of $\mathrm{CO}$ poisoning can be justified as CO-induced progressive oxidative stress is proved to play an important role in pathophysiology of $\mathrm{CO}$ poisoning, either in 
initial presentation or after $\mathrm{O}_{2}$ therapy, and even if $\mathrm{COHb}$ blood levels return to normal by $\mathrm{O}_{2}$ therapy, a high blood level of ADMA, which is an oxidative stress biomarker, must be a sure finding (Yazar et al., 2019).

\section{Conclusion:}

Level of $\mathrm{COHb}$ alone is an insufficient biomarker for assessing the severity of acute $\mathrm{CO}$ poisoning, it can only support the initial diagnosis. In assessing the severity of acute $\mathrm{CO}$ poisoning, both ADMA and Net-1 are better biomarkers as compared with $\mathrm{COHb}$.

As a biomarker of acute $\mathrm{CO}$ poisoning, ADMA is better than Net-1. In diagnosis of chronic CO poisoning, both ADMA and Net-1 are as dependable as $\mathrm{COHb}$.

\section{Recommendations:}

- Usage of ADMA and Net-1 as biomarkers for diagnosis and assessment of the severity of acute $\mathrm{CO}$ poisoning, as well as for diagnosis of chronic $\mathrm{CO}$ poisoning.

- Conduction of further studies on a large number of patients with acute and chronic $\mathrm{CO}$ poisoning in different localities.

\section{Limitations of study:}

Small sample size (30 patients with acute CO poisoning): this was due to the low rate of cases of acute $\mathrm{CO}$ poisoning admitted to Benha Poisoning Control Unit, plus many of the admitted cases refused to give a consent to participate in the study. In addition, there were limited financial resources.

\section{Acknowledgment}

Deep gratitude to our colleges at faculty of medicine, Benha University, for their continuous support and cooperation. http://www.fmed.bu.edu.eg

Conflict of Interest (if any): 'The Authors declare that there is no conflict of interest'

\section{References}

Abass, M.; Arafa, M.; EL-shal, A.; et al. (2017): "Asymmetric dimethylarginine and heart-type fatty acid-binding protein 3 are risk markers of cardiotoxicity in carbon monoxide poisoning cases in Zagazig university hospitals". Hum. Experim. Toxicol., 36 (3): 247-255. doi:10.1177/0960327116646621

Bol, O.; Koyuncu, S.; Günay, N. (2018): "Prevalence of hidden carbon monoxide poisoning in auto service workers; a prospective cohort study". J. Occup. Med. Toxicol., 13 (35):1-7. doi:10.1186/s12995-018-0214-9

Bono, R.; Piccioni, P.; Traversi, D.; et al. (2007): "Urban air quality and carboxyhemoglobin levels in a group of traffic policemen". Sci. Total Environ., 376:109-115. doi:10.1016/j.scitotenv.2007.01.086

Chen, J.; Yuan, D.; Yang, S. et al. (2019): "Serum netrin-1 serves as a prognostic biomarker of aneurysmal subarachnoid hemorrhage". Clin. Chim. Acta, 495: 294-300. doi.org/10.1016/j.cca.2019.04.080

Crapo, R.O.; Jensen, R.L.; Hegewald, M.; et al. (1999): "Arterial blood gas reference values for sea level and an altitude of 1,400 meters". Am. J. Respir. Crit. Care Med., 160 (5):1525-1531. doi: 10.1164/ajrccm.160.5.9806006 
Daliang, Z.; Lifang, X.; Hong, F.; et al. (2019): "Netrin-1 plays a role in the effect of moderate exercise on myocardial fibrosis in rats". PLoS ONE, 14 (2): e0199802. doi: 10.1371/journal. Pone. 0199802.

Dymara-Konopka, W. and Laskowska, M. (2019): "The role of nitric oxide, ADMA, and homocysteine in the etiopathogenesis of preeclampsiaReview". Int. J. Mol. Sci., 20: 2757. doi: 10.3390/ijms20112757

Eichhorn, L.; Thudium, M.; Jüttner, B. (2018): "The diagnosis and treatment of carbon monoxide poisoning". Dtsch. Arztebl. Int., 115: 863-870. doi:10.3238/arztebl.2018.0863

Gedikli, U.; Emektar, E.; Corbacioglu, S.K.; et al. (2019): "Determination of netrin-1 levels and its relationship with neurotoxicity in carbon monoxide poisoning". Hum. Experi. Toxicol., 38 (5): 561-566. doi: $10.1177 / 0960327119828124$

Guo, D.; Zhu, Z.; Zhong, C.; et al. (2019): "Increased serum netrin-1 is associated with improved prognosis of ischemic stroke an observational study from CATIS". Stroke, 50: 845-852. doi: 10.1161/STROKEAHA.118.024631.

Huang, C.; Ho, C.; Chen, Y.; et al. (2019): "Increased risk for hypothyroidism associated with carbon monoxide poisoning: a nationwide populationbased cohort study". Sci. Reports, 9:16512. doi:10.1038/s41598-01952844-9

Jung, J. W. and Lee, J. H. (2019): "Serum lactate as a predictor of neurologic outcome in ED patients with acute carbon monoxide poisoning". Am. J. Emerg. Med., 37: 823-827. doi: 10.1016/j.ajem.2018.07.046
Khothari, C.R. (2004): "Processing and Analysis of Data". In: Research Methodology: Methods and Techniques, 2nd Edition, New Age International (P) Limited Publishers, New Delhi, Chapter 7, P.P.122-152. ISBN (13): 978-81-2242488-1

Koyuncu, S.; Bol, O.; Ertan, T.; et al. (2019): "The detection of occult $\mathrm{CO}$ poisoning through noninvasive measurement of carboxyhemoglobin: A cross-sectional study". Am. J. Emerg. Med., $\quad 1: 158383$. doi: 10.1016/j.ajem.2019.158383

Lin, Z.; Jin, J.; Bai, W.; et al. (2018): "Netrin-1 prevents the attachment of monocytes to endothelial cells via an anti-inflammatory effect". Molec. Immunol., 103: 166-172. doi: 10.1016/j.molimm.2018.08.021

Liyona, P.; Hannah, S. K.; Paul, E.S.; et al. (2019): "Symmetric dimethylarginine (SDMA) is a stronger predictor of mortality risk than asymmetric dimethylarginine (ADMA) amongst older people with kidney disease". Annals Clin. Biochem., 56 (3): 367-374. doi: $10.1177 / 0004563218822655$

Masters, T.; Willenbring, B.; Westgard, B.; et al. (2019): "Availability of bedside and laboratory testing for carbon monoxide poisoning in the upper midwestern united states". Western J. Emerg. Med., 20 (3): 506-511. doi:10.5811/westjem.2019.2.41428

Nair, A.; Nandini, M.; Adappa, S.; et al. (2017): "Carbon monoxide exposure among police officers working in a traffic dense region of Southern India". Toxicol. Indus. Health, 33 (1): 46-52. doi: $10.1177 / 0748233716654071$

Oliva-Damaso, E.; Oliva-Damaso, N.; Rodriguez-Esparragon, F.; et al. (2019): "Asymmetric (ADMA) and 
symmetric (SDMA) dimethylarginines in chronic kidney disease: a clinical approach". Int. J. Mol. Sci., 20: 3668. doi: $10.3390 /$ ijms 20153668

Persson, H.E.; Sjoberg, G.K.; Haines, J.A.; et al. (1998): "Poisoning severity score. grading of acute poisoning". J. Toxicol. Clin. Toxicol., 36 (3): 205-213. doi: $10.3109 / 15563659809028940$

Ramesh, G.; Berg, A.; Jayakumar, C. (2011): "Plasma netrin-1 is a diagnostic biomarker of human cancers". Biomarkers, 16 (2): 172-180.

doi:10.3109/1354750X.2010.541564.

Reumuth, G.; Alharbi, Z.; Houschyar, K.S.; et al. (2019): "Carbon monoxide intoxication: What we know". Burns, 45: 526-530.

doi:10.1016/j.burns.2018.07.006

Schulze, F.; Wesemann, R.; Schwedhelm, E.; et al. (2004): "Determination of asymmetric dimethylarginine (ADMA) using a novel ELISA assay". Clin. Chem. Lab. Med., 42 (12): 1377-1383. doi: 10.1515/CCLM.2004.257
Sun, L.; Ju, T.; Wang, T.; et al. (2019): "Decreased netrin-1 and correlated Th17/tregs balance disorder in AB1- 42 induced alzheimer's disease model rats". Front. Aging Neurosci., 11:124. doi: 10.3389/fnagi.2019.00124

Tomaszewski, C. (2006): "Carbon Monoxide". In: Goldfrank's Toxicologic Emergencies. By: Flomenbaum, N.E.; Goldfrank, L.R.; Hoffman, R.S., et al. (eds.), McGraw-Hill, New York, $8^{\text {th }}$ ed., chapter (120), P.P. 1690-1705.

Veronesi, A.; Pecoraro, V.; Zauli, S.; et al. (2017): "Use of carboxyhemoglobin as a biomarker of environmental $\mathrm{CO}$ exposure: critical evaluation of the literature". Envir. Sci. Pollu. Res., 24:25798-25809. doi: 10.1007/s11356017-0270-1

Yazar, A.; Akın, F.; Sert, A.; et al. (2019): "Is asymmetric dimethylarginine a useful biomarker in children with carbon monoxide poisoning?" Pediatr. Emerg. Care, 35 (3): 226-230. doi: 10.1097/PEC.0000000000001758. 


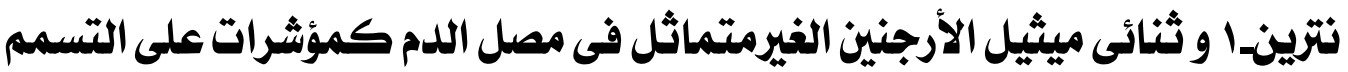

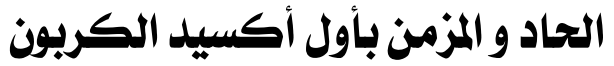

\author{
إسلام سامى متولى' ، أميمة محمود حسن 'عبد المنعم جودة ملبولى' \\ من أقسام ’ الطب الثرعى و السموم الأكلينيكية، ` الصحة العامة والبيئة و طب الصناعات،

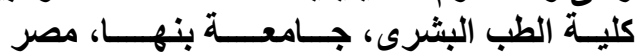

يتم تشخيص حالات التسمم بأول أكسيد الكربون بشكل تقليدي عن طريق الكثف عن مستوى الكربوكسي

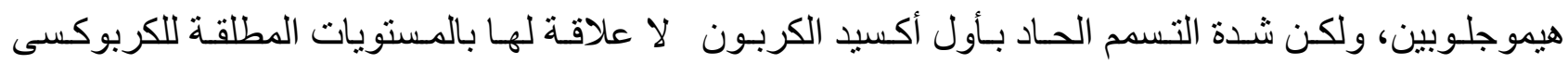

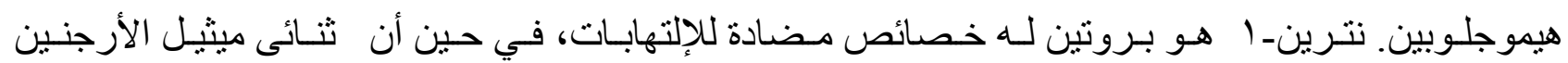

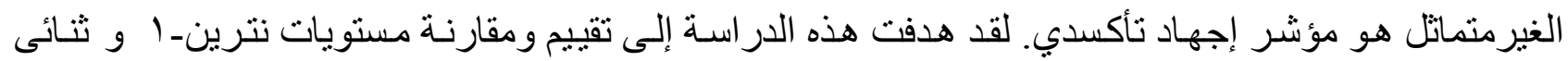

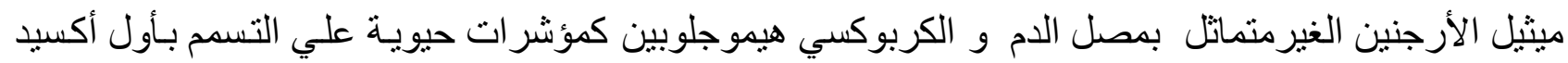
الكربون. أجريت هذه الدراسة السريرية المستعرضة على • 9 فردا بعد أخذ الموافقة المستنيرة منهم، على النحو هوتين

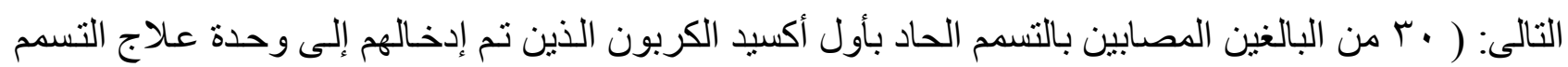

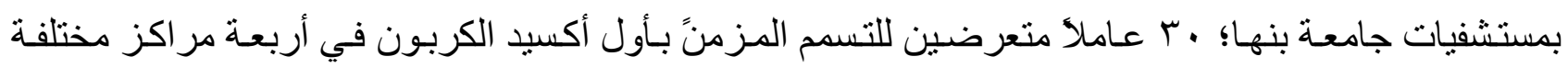

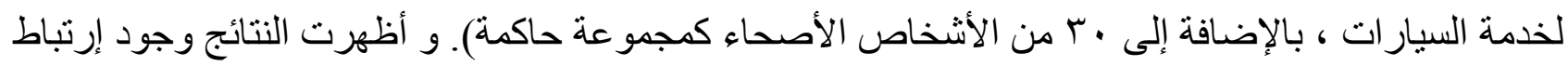

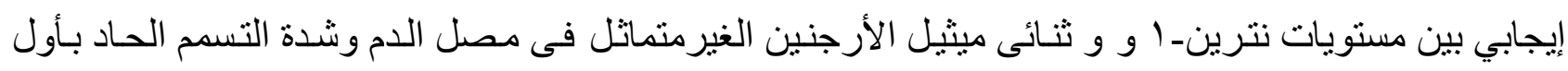
أكسيد الكربون عند أستقبال الحالات بوحدة علاج التسمم وكذلك بعد العـاج بالأوكسجين، و كان هنالك إرتباط إيجابي بين مستوي الكربوكسي هيموجلوبين ومستويات كل من نترين- ا و ثنائى ميثيل الأرجنين الغيرمتماثل

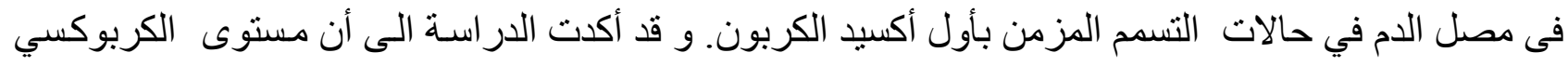
هيموجلوبين يدعم فقط التشخيص الأولي للتسمم الحاد بأول أكسيد الكربون، كما خلصت التئ الدر اسة الى ان كلا" من

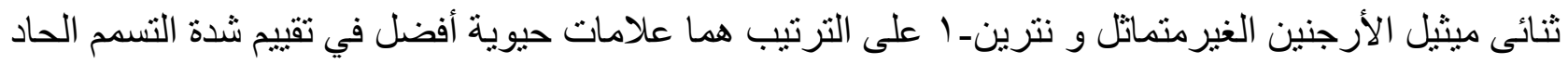

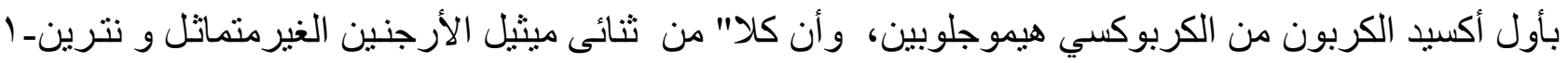

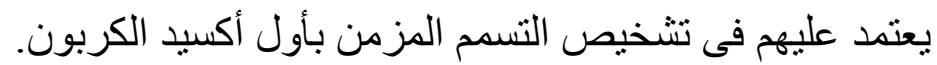

